\title{
Two species of supranivale insects new for Kampinos National Park
}

\author{
Przemysław TROJAN \\ Museum and Institute of Zoology, Polish Academy of Sciences, Wilcza 64, 00-679 Warszawa, Poland: \\ e-mail:trojan@miiz.waw.pl
}

\begin{abstract}
Chionea (Niphadobata) lutescens Lundstr. and Boreus westwoodi Hagen were caught in Moericke's trap during a snowy December in the year 2004 in Kampinos National Park.
\end{abstract}

Key words: Chionea lutescens, Boreus westwoodi, Kampinos National Park.

\section{INTRODUCTION}

The imagoes of some "wingless" insects appear only in winter (Soszyńska, 2004). They are representatives of the genera Boreus Latreille (Mecoptera, Boreidae) and Chionea Dalman (Diptera, Limoniidae). In the check-list of Polish Boreidae (Czechowska 2007), two species of Boreus Latr. are listed as occurring over the entire Polish territory, both entries being accompanied with question marks. In the check-list of Limoniidae (Wiedeńska 2007), no information is given concerning the distribution of the species. More information on the occurrence of the species can be found in papers of Krzeminski (1978, 1982 and 1984). They concern to the occurrence in South Poland. Sznabl (1881) and Demska (1989), in their papers on Diptera, give no information on the occurrence of Nematocera in the Mazovian Lowland. The species Boreus westwoodi Hagen (Meinander 1962, Mayer 1938) and Chionea lutescens Lundstrőm (Krzemiński 1984) are known from Europe.

\section{STUDY AREA, MATERIAL AND METHODS}

During the snowy winter of 2004/2005, Moericke's traps were placed on the ground in two types of habitats in the Kampinos National Park. The first was a rye-grass meadow association (Arrhenatheretum medioeuropeum), the second was a fresh pine forest (Peucedano-Pinetum). The traps were exposed from November 14, 2004, to March 16, 2005. Five yellow plastic bowls were disposed in both sampling areas, filled with a preserving solution consisting of ethylene with glycol. The samples were taken in the surroundings of Nowe Grochale.

\section{RESULTS}

The insects caught on the ground of the meadow and pine forest included five specimens of the "wingless" insects. The species of Chionea Dalman were determined according to Krzeminnski $(1978,1982)$ and the species of Boreus Latreille were identified in accordance with the papers of Dorochova \& Martynova (1987) and Martynova (1954). They seem new for Mazovian Lowland.

Chionea (Niphadobata) lutescens Lundstrőm, 1907. 2 qq, 1 ठै 2-8. 12. 2004; and 1 \% $18-26.12$ 2004. All these specimens were caught on the rye-grass meadow (Arrhenatheretum medioeuropeum). Pinetum).

Boreus westwoodi Hagen, 1866. $1 \nmid 2$ - 18. 12. 2004 fresh pine forest (Peucedano- 


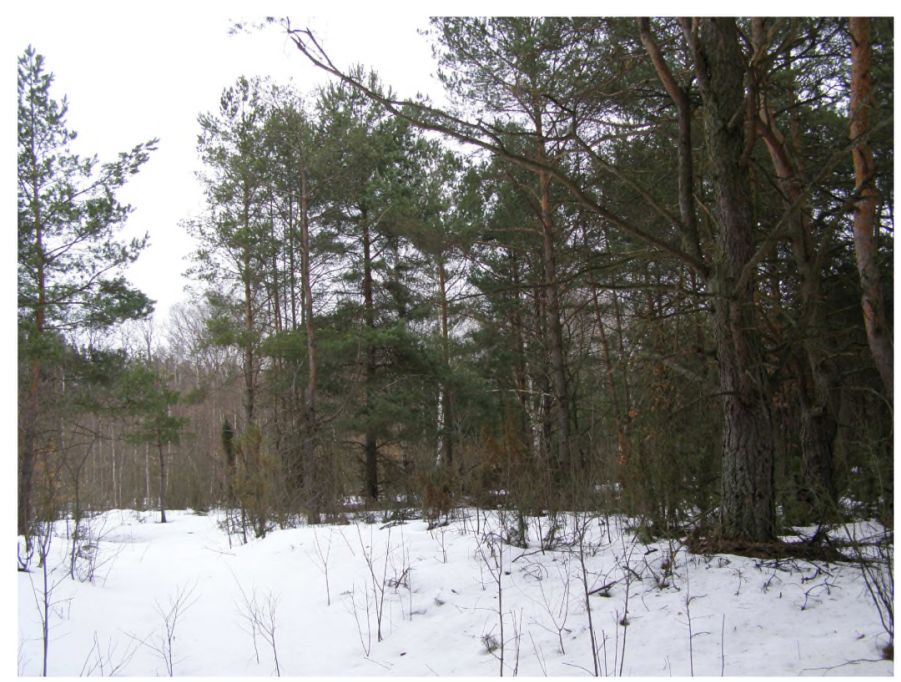

Fig. Fresh pine forest (Peucedano-Pinetum) in Kampinos National Park. (photo E. Wegner)

\section{REFERENCES}

Czechowska W. 2007. Boreidae. In: Bogdanowicz W., Chudzicka E., Piliputk I. \& Skibinsska E. (eds), Fauna of Poland - characteristics and checklist of species. Vol. 2, pp. 269-272. Muzeum i Instytut Zoologii PAN, Warszawa. 506 pp.

DEMSKA L. 1989. Nematocera (Diptera) of moist meadows on the Mazovian Lowland. Memorabilia Zoologica 43: $303-313$.

Dorochova G. I. \& Martynova O. M. 1987. 26. Riad Mecoptera - Skorpionovye muchi. In: Medvedev G. S. Opredelitel Nasekomych Evropejskoj Czasti SSSR 4: 97-106.

KRZEMIŃSKI W. 1978. Rodzaje Chionea Dalm. i Niphidobata Ender. (Diptera, Limoniidae) z terenu Polski. Zeszyty Naukowe Uniwersytetu Jagiellońskiego, Prace Zoologiczne. Kraków, 24: 109-127.

KRZEMIŃSKI W. 1982. Contributions to the taxonomy of the European species of Chionea Dalman (Diptera: Limoniidae). Entomologica Scandinavica 13: 193-200.

KRZEMTNSKI W. 1984. Limoniidae of Poland (Diptera, Nematocera). Part I: subfamily Eriopterinae. Acta Zoologica Cracoviensia $27(20): 437-518$.

MarTYNOVA O. M. 1954. Skorpionnicy (Mecoptera) fauny SSSR. I. Trudy Zoologičeskogo Instituta Akademii Nauk SSSR, 15: 54-66.

MEINANDER M. 1962. The Neuroptera and Mecoptera of eastern Fennoscandia. Fauna Fennica 13: 1-96.

MAYER K. 1938. Rod Boreus (Panorpata - Boreidae) v Československu. Folia entomologica: 129-140.

SOSZYŃSKA A. 2004. The influence of atmospheric factors on supranivean activity of flies (Diptera) in Central Poland. European Journal of Entomology 103(3): 481-490.

SZNABL J. 1881. Spis owadów dwuskrzydlych zebranych w Królestwie Polskiem i Gubernii Mińskiej. Pamiętnik Fizyjograficzny, 1: 357-390.

Wiedeńska J. 2007. Limoniidae. In: Bogdanowicz W., Chudzicka E., Pilipiuk I. \& Skibinska E. (eds), Fauna of Poland - characteristics and checklist of species. Vol. 2, pp. 74-77. Muzeum i Instytut Zoologii PAN, Warszawa. $506 \mathrm{pp}$.

\section{STRESZCZENIE}

\section{[Dwa nowe gatunki naśnieżnych owadów w Kampinoskim Parku Narodowym]}

W trakcie badań fauny naśnieżnej podczas zimy 2004 roku złowiono w pułapki Moericke okazy Chionea (Niphidobata) lutescens Lundstr. oraz Boreus westwoodi Hagen. Obydwa gatunki nowe dla Kampinoskiego Parku Narodowego i prawdopodobnie Mazowsza. Obydwa gatunki zostały złowione w Polsce, brakuje jednak informacji w najnowszym piśmiennictwie o ich występowaniu na Mazowszu. 